\title{
Economic Community Empowerment Through Tourist Village Development
}

\author{
AZIS MUSLIM \\ Dakwah and Communication of Yogyakarta Sunan Kalijaga State Islamic University \\ email: muslimtenan@gmail.com
}

\begin{abstract}
The village is the governance structure at the bottom and directly in contact with the public. The village has the potential and assets that can be developed to build public welfare. Therefore, the village government has a strategic role in the economic empowerment of the community. The village government of Bleberan exploits the potential and assets for economic empowerment of communities through the development of tourism village. This study aims to assess the measures undertaken by the Bleberan village government in building a tourism village and its impact on the local economy. Research is conducted qualitatively by the method of collecting data through observation, interview, and documentation. In addition, the questionnaire is used to complete the data. Based on the research it is found that the construction of tourism village has done through the stages of village potential exploration, building a dream, forming a strategy, and taking action. Meanwhile, economic empowerment is done through awareness, provision of facilities, and training of skills. The result of the development of tourism village gives impact on work opportunities, increased income, and investment growth in the tourism business for the local community.
\end{abstract}

Keywords: impact, tourism village, economic empowerment.

\section{Introduction}

Recently, tourism develops very rapidly. In some countries, tourism serves as a motor to open job opportunity and economic income source (Sudiarta, 2005: 4). It is in line with tourism program promoted by the Indonesian government, as an alternative development approach aiming to improve economic growth, to deal with unemployment, to remove poverty, and to improve the people welfare. Tourism development ending up in such objective should involve the community as one of its stakeholders. As, in principle, the community has a large authority and responsibility for tourism management.

Damanik (2009: 131-133) stated that tourism development is driven by government and tend to ignore public participation which often facing the crucial problem and failure. Meanwhile, tourism building on the community's initiative and also managed by the community itself will tend to be successful. For that reasons, community (public) participation in tourism management becomes an important factor, because they can understand the tourism and dominate the development in their areas. In addition, tourism is a service industry that highly dependent on desire and cooperation with local government.

Considering the importance of tourism's role in development, tourism can be used as a strategic media in economic empowerment by giving the community as wide as a possible opportunity of developing and managing tourism all at once (Haryani, 2014). Bleberan Village of Playen Sub District of Gunung Kidul Regency is a village building tourism by giving the community as wide as a possible opportunity of developing and managing it. Potential natural resources it has such as waterfall, cave, olden time site, camp area, and fishing pond are managed well thereby having high selling value. All of them are

Received: May 03, 2016, Revision: November 16, 2016, Accepted: December 30, 2016

Print ISSN: 0215-8175; Online ISSN: 2303-2499. Copyright@2016. Published by Pusat Penerbitan Universitas (P2U) LPPM Unisba Accredited by DIKTI. SK Kemendikbud, No.040/P/2014, valid 18-02-2014 until 18-02-2019 
packaged in a ready-to-market product with tourist village brand.

Bleberan is categorized as poor village because 54 percents of the total population occupying this area belong to poor category, with numbers of 730 households out of total 1,347 households. The poverty problem in Bleberan Village is due to geographical condition. Most populations of this village, with $16,262,170$ ha area width, have farming as their livelihood with dry field and rain-fed farm. Meanwhile, only 150,000 ha farmland relying on irrigation channel. These farmlands are located around the waterfall. In addition, a geographic condition also makes Bleberan Village community often encountering clean water crisis. During the dry season, nearly all households buy 1 (one) to 5 (five) tanks of clean water per month with price of IDR 100,000 (a hundred thousands rupiahs) per tank for daily life. On the other hand, Original Village Income (PAD) of Bleberan village is, on average, less than IDR $1,000,000,-$ (one million). It is very difficult to alleviate poverty (Bleberan Village's Document, 2009).

Being apprehensive with this condition, Triharjono as the Head of Bleberan Village, designs tourist village development. This tourist village development aims to build a better economic community. The development of Bleberan Tourist Village has been pioneered since 2007 and newly launched on July 2010, while the explosion of tourists started to occur since 2011 with business income of IDR $117,802,300 .-$. In 2012, its business income reached IDR 1,096,010,600.- and increase continuously over years. In addition, Bleberan Tourist Village has absorbed 102 workers out of those having independent business such as food stall, home-stay and etc (Document of Bleberan Tourist Village Management, 2015). This is interesting to study more in-depth in order to obtain more detailed information so that the result of the research can be used as the reference for the government to make policy concerning economic community empowerment through tourism and for other areas to build similar businesses. This study will focus on the attempt of building the village tourist and its effect on the local community's economy.

Tourist Village is a rural area offering the circumstance of village originality, whether social, cultural, custom, and environment (Hadiwijoyo, 2012: 68). Tourist village development requires cooperation between government, private and local community
(Oktini, 2004: 269). In addition, tourist village development also needs mature planning in order to be an attractive tourist object (Permanasari, 2010: 64).

Furthermore, Raharjana (2012: 230) confirmed that tourist village development should begin with planning. To set an appropriate target, the planning should be conducted through a participatory method involving the community completely in its entire process, so that its plan should be based on the studies on the problem faced and the potencies existing within society. In this way, the society is given the opportunity to resolve the problem they face and conveying ideas as the solution to the planning process based on their ability. When this participatory planning process works, it is expected to improve the role of society. It means that community empowerment process can run in tourist village development. When the empowerment process works, the community can expectedly to implement, maintain, and enjoy the results of tourist village development.

Economically, the result of tourist village development, of course, can be enjoyed by all classes of society. The society that capture certain business opportunity would enjoy the presence of tourist village. On the other hand, the community that cannot capture the oportunities would be marginalized and alienated in their own area. For that reason, there should be a community empowerment in economic sector intended to those incapable of capturing the business opportunity to enable them to enjoy the result of their development. On the other hand, economic empowerment is also required for those who can capture the business opportunity by organizing their business to enable them to run economic activity more tidily to the tourists.

Prayogi (2011: 78) gave three alternatives that can be used for economic empowerment to the members of society that cannot capture the business opportunity. The first is education. This alternative is given to improve knowledge and ability, for example to improve the knowledge on tourist object and foreign language ability. Those who unemployed should be given opportunity to learn about tourist object and to improve their foreign language ability by giving scholarship so that they will be a tourist guide in the future. The second is informal training. This alternative is given to provide skill, for example by providing short 
course in craft and culinary art. Those trained are expected to open their new business immediately. The third is the involvement in tourism management. This alternative is given to those having no business in order to participate in tourism management, so that they have sense of belonging and do not feel alienated in their own area.

More detailed, Muslim (2014: 236242) explained economic empowerment model that can be referred to deal with the problem above. The empowerment model offered encompasses four stages: input, process, output and outcome. The inputs of empowerment that should be available are financial institution, facilitator, empowered community, and partner institution. The financial institution serves to build financial capital accessible to the community, particularly the poor one. This institution can be cooperative or baitul maal established by the community itself. Facilitator serves to help the targeted community to identify and to develop their potential. Meanwhile, partner institution serves to help deal with the problem irresolvable by the facilitator and targeted community. The next is empowerment process. Empowerment process is conducted by building mental consciousness, entrepreneur consciousness, capacity building, and empowering the targeted community. The process carried out in four stages is expected to get output including character reinforcement, job opportunity establishment, comfortable work environment construction, and both internal and external network construction. Based on the output yielded, an outcome is expected to growth in the form of economic community empowerment. This economic community empowerment is characterized by the emergence of honest independent entrepreneurs who have many networks and develop their business easily. This model can be seen more clearly in the figure below.

This study was a qualitative research with phenomenological approach. The advantages of this type and approach to the problem studied are first: it can be the source of more entrenched description and explanation, particularly concerning the process occurring in the local context. Secondly, it can build the closer relationship with informants as the target of study. Thirdly, it gives the author the opportunity of disclosing the chronology of social events, of assessing and giving an explanation about the causal relationship occurring in a local event. Fourthly, it is easier to answer the problem posed (Muslim: 2014: 67-68).

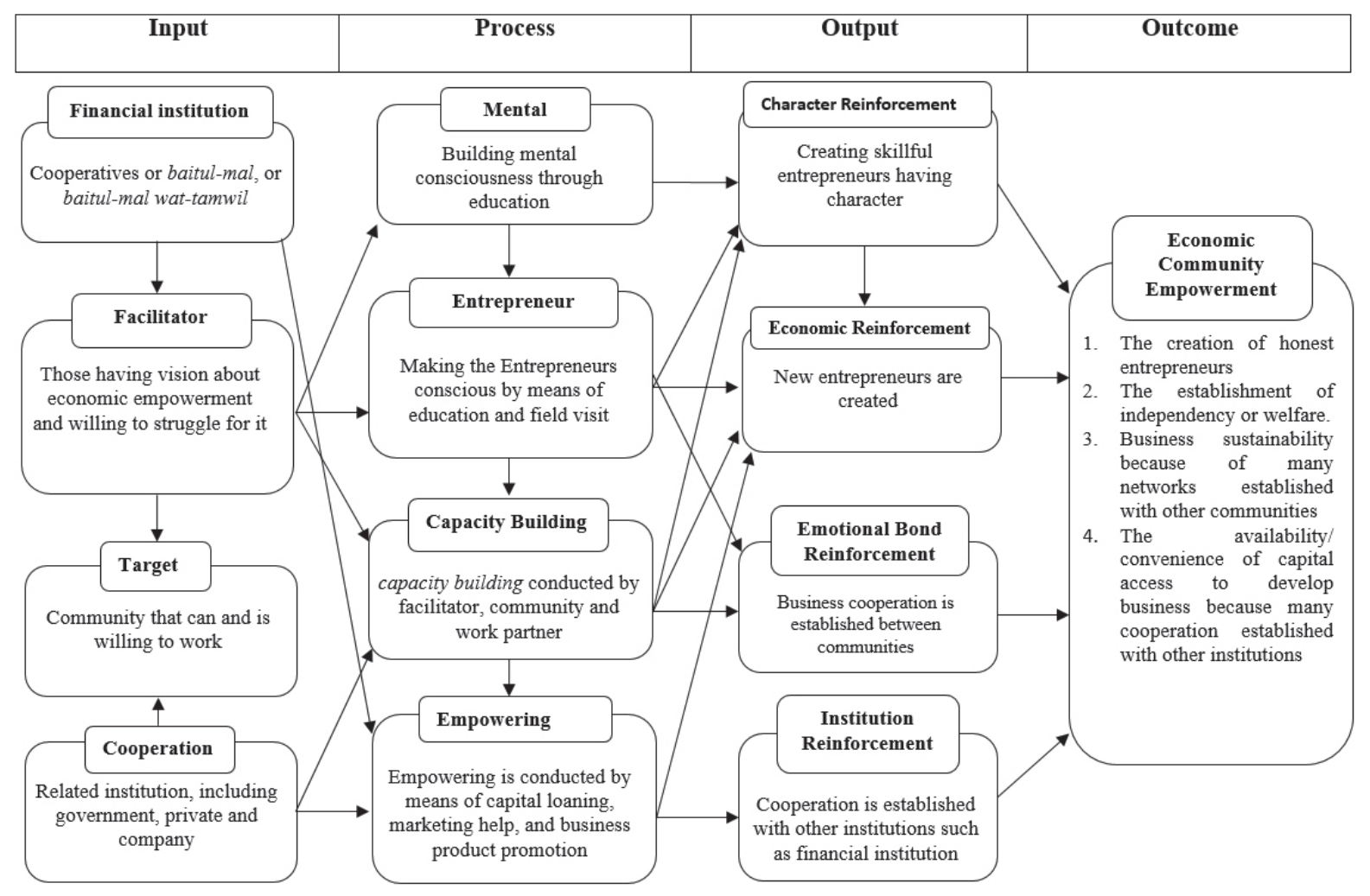

Figure 1. Economic Community Empowerment Adapted from Muslim's Model 
This research was taken place in Bleberan Village of Playen Sub District of Gunung Kidul of Daerah Istimewa Yogyakarta Province. The key informants in this research were a business performer, tourist village employees, and tourist village initiators, while the supporting informants were Bleberan villagers (in addition to the business performer, employees and tourist village initiators). Data was collected using observation, interview, documentation and questionnaire techniques. The questionnaire commonly used in this quantitative research was used for the survey in order to complete the primary data. Data validation was carried out through observing persistently and examining the data with triangulation. Meanwhile, technique of analyzing data used was Miles and Huberman's interactive model of data analysis.

\section{The Attempt of Building Bleberan Tourist Village}

The village is the bottom government structure pertaining having direct contact with the community. For that reasons, the role of village government becomes very strategic in building community welfare. When every village becomes prosperous, it can be ensured that the state will be prosperous as well. However, when the state is prosperous, every village uncertainty becomes prosperous. This perspective seems to justifies the government's reason to allocate many funds to every village in Indonesia.

Regardless the presence of fund distributed by the central government to village, village government should build the community welfare creatively. Triharjono, for example, a village head in Bleberan Village occupying his position from 2006 to 2014, tries to build his village by developing tourist village. He did it because he was motivated to build his community welfare since PAD (Original Village Income) and annual fund allocation obtained from regency government are very limited.

This tourist village has been pioneered since 2007 by involving 40 (forty) persons as administrator, but this attempt has been failed. A large number of administrators and less bravery to sacrifice are the strong reasons of this failure. This failure did not break Triharjono's spirit to build tourist village in his jurisdiction. In early 2010, he assigned 6 (six) persons including himself to be the new administrators of a tourist village. These six (6) persons work hard and sacrifice bravely to achieve the success. The procedures are taken from the beginning to the achievement of success are as follows:

Firstly, exploring potencies and analyzing them from weakness and opportunity. Tourist village is a tourism offering a circumstance reflecting the originality of rural area, from social-economic, social-cultural life aspects, tradition, unique building architecture, original natural condition, and typical village layout. For that reason, according to Triharjono, exploring the village's potency becomes the important and fundamental measures to be taken for the tourist village development to be realized (interview with Triharjono as the initiator of Bleberan Tourist Village). To explore the village's potency smoothly, Triharjono established a team of six (6). The team was in charge of exploring the village potential and analyzing the opportunity that can be developed and looking for a weakness that should be repaired.

The village potential which can be found and developed into tourist village is, among other, natural potency. This potential is a water source. Bleberan Village has four (4) large water sources: Jambe water source with 40-60 liter per second flow-rate, Ngandong with 30 liters per second, Kedung Poh with 15 liters per second, and Ngumpul with 40-60 liter per second. All of this water sources end up in Sri Gethuk waterfall so that it has never been dry even in dry season. Nevertheless, Sri Gethuk waterfall cannot be utilized for farming irrigation by local community, because it flows to Oyo River, the location of which the stream is far lower than the community-owned farm. For that reason, this waterfall seems has no benefit and is ignored by local community. Moreover, the location of waterfall is far from the people's houses and less affordable because there is no road access.

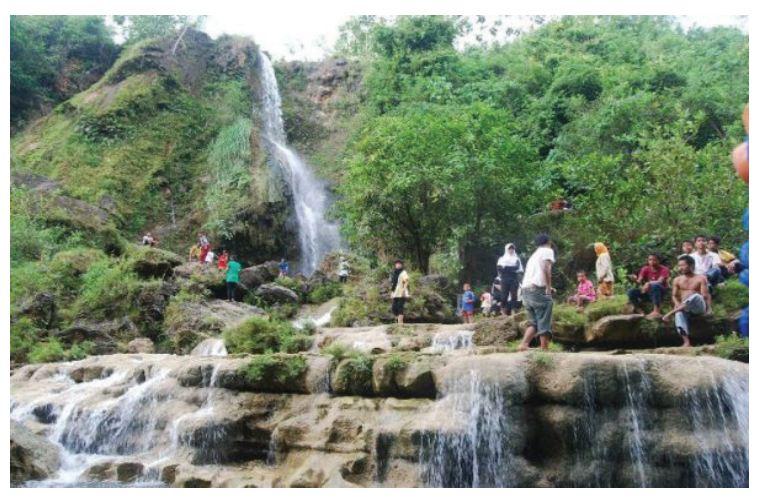

Figure 2. Sri Gethuk Waterfall 
In addition to a water source, natural potencies this village has are Rancang Kencono Cave and Olden Times Site. Rancang Kencono Cave is the one replete with a story from prehistory age to Mataram soldier struggle age. The cave, in which Klumprit (terminalia edulis) grows and estimated more than two (2) centuries old, according to the local people, has been used to develop a strategic plan in the attempt of expelling Dutch colonial from Kasultanan Ngayogyakarta Hadiningrat. Because it was used to design a strategy for the lofty purpose, this cave was named Goa Rancang Kencono. Before 2010, this cave was not well-known to outsiders despite it's affordable and proximate location to the people houses. This cave has a wide room, thereby it can be used to hold a meeting. It is of course, interesting to everyone who wants to hold a meeting in an open and natural space. In addition to Rancang Kencono Cave, there is also old times site in Bleberan. This site is composed of tidily and regularly piled stones. This site is actually interesting, but because it has not been well-known to outsider, there are only few visitors have come to this place.

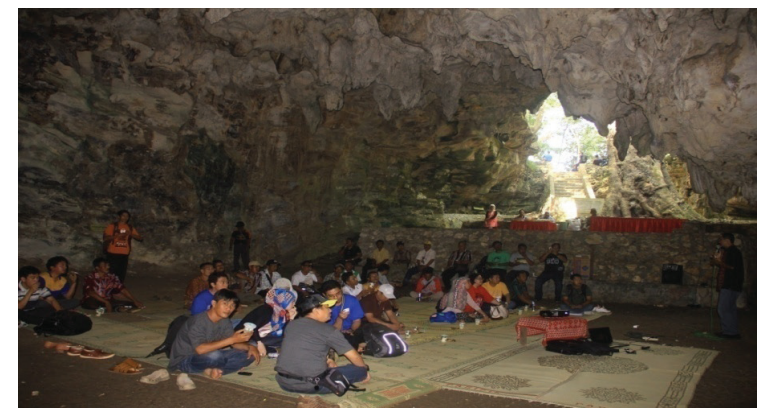

Figure 3. One of the rooms inside Rancang Kencono Cave

The teak woods spreading to nearly entire farm land become the natural potential that can be developed into tourist area as well. Kohar said that this natural potential in the form of teak woods can be developed into outbound site, as cited as follows:

"There are still many teak woods in this area. It is very interesting to be outbound site. In addition to its cool weather, its scenery is also beautiful. At that time, we should make the community conscious and establishing Pokdarwis (Tourism-Conscious Group) to develop this outbound tour" (Interview with Kohar as the Members of Bleberan Tourist Village Initiator Team).

In addition to natural potency, the cultural potential that exist and can be developed into tourist objects in Bleberan village are nyadran, rasulan, and tumpeng robyong. Nyadran is ancestor grave pilgrimage ceremony or the village founder fledgling. Rasulan is a selamatan ceremony held during harvest time. Tumpeng robyong is the symbol of safety, fertility, and welfare. These three traditions have uniqueness perhaps not existing in another area, so that this tradition is feasible to be packaged and sold as tourist object.

Jatilan, doger and karawitan are other potentials that the Bleberan Village has. Just like the cultural potencies above, these potencies can be packaged and sold as the tourist object. Attractive and unique packaging and affordable price will make this art sold out.

Other potencies that found and developable are institutional and community potencies. Institutional potency like Karang Taruna (youth organization), Female Farmer Group (KWT), Kader Sehat (Health Cadre), Hamlet Family Welfare Empowerment (PKK Dusun), and Villager Self-Helping Institution (LKMD) are important elements that can be invited to build and to realize the tourist village simultaneously. With these institutions the community's potencies including mutual cooperation, the spirit of commonality, the spirit of getting out of backwardness, the spirit of building, and spirit of going forward become the potencies that should be developed continuously as well.

The analysis on the weakness and the opportunity of tourism potency that the Bleberan Village has can be presented in the table below 1 .

The table shows that the opportunity of building tourism village for Bleberan village is very possible. The potencies existing are feasible to be developed into tourist object. The good and attractive packaging of tour package from the existing opportunities will be a distinctive attraction for the tourists. For that reasons, the next important business is how to build the dream of realizing a tourist village.

Developing a tourist village, according to Triharjono, cannot be done individually or by the government-established team only, but it should involve all components of the local community. For that reasons, the attempt taken to build that dream starts with developing tourist village concept. Tourist village concept is formulated by a small team consisting of six (6) persons. After the concept has been approved, it will be discussed with 
Table 1

Classification of Tourist Potencies and Opportunities in Bleberan Village

\begin{tabular}{|c|c|c|c|c|}
\hline No & Potency & Form & Weaknesses & Opportunities \\
\hline \multirow[t]{4}{*}{1.} & Nature & 1. Water source & $\begin{array}{l}\text { Poorly maintained and } \\
\text { many bushes growing }\end{array}$ & Outbond and tracking \\
\hline & & 2. Sri Gethuk waterfall & $\begin{array}{l}\text { 1. Bad and narrow road } \\
\text { toward the location } \\
\text { 2. Far from people } \\
\text { residence and less } \\
\text { affordable }\end{array}$ & $\begin{array}{l}\text { Water tour such as } \\
\text { boat rent, bathing } \\
\text { place, and fishing }\end{array}$ \\
\hline & & $\begin{array}{l}\text { 3. Rancang Kencono } \\
\text { Cave }\end{array}$ & $\begin{array}{l}\text { Many stalactites are not } \\
\text { active, thereby not } \\
\text { dropping water }\end{array}$ & $\begin{array}{l}\text { Meeting or gathering } \\
\text { place in open nature }\end{array}$ \\
\hline & & 4. Olden times site & $\begin{array}{l}\text { 1. Narrow road toward the } \\
\text { location } \\
\text { 2. No signpost }\end{array}$ & $\begin{array}{l}\text { Education tour: } \\
\text { history and } \\
\text { archeology }\end{array}$ \\
\hline 2. & Culture & $\begin{array}{l}\text { 1. Nyadran } \\
\text { 2. Bersih Desa } \\
\text { 3. Tumpeng Robyong }\end{array}$ & $\begin{array}{l}\text { 1. Starting to be forgotten } \\
\text { by community } \\
\text { 2. Form modification } \\
\text { occurs }\end{array}$ & $\begin{array}{l}\text { Cultural tour by } \\
\text { reactivating cultural } \\
\text { event }\end{array}$ \\
\hline 3. & Art & $\begin{array}{l}\text { 1. Jatilan } \\
\text { 2. Doger } \\
\text { 3. Karawitan }\end{array}$ & $\begin{array}{l}\text { 1. Limited number of cadre } \\
\text { 2. Started to be abandoned } \\
\text { by community }\end{array}$ & $\begin{array}{l}\text { Art tour packaged into } \\
\text { show (performance) } \\
\text { package }\end{array}$ \\
\hline 4. & Institution & $\begin{array}{l}\text { 1. Karang Taruna } \\
\text { 2. KWT } \\
\text { 3. Kader Sehat } \\
\text { 4. PKK Dusun } \\
\text { 5. LKMD }\end{array}$ & $\begin{array}{l}\text { 1. Understanding poorly } \\
\text { the mindset as farmer } \\
\text { among the service } \\
\text { provider } \\
\text { 2. Poor knowledge on } \\
\text { tourism. } \\
\text { 3. Limited number of } \\
\text { network possessed. }\end{array}$ & $\begin{array}{l}\text { Tourist guide and } \\
\text { tourism manager }\end{array}$ \\
\hline 5. & Society & $\begin{array}{l}\text { 1. Gotong royong } \\
\text { 2. Commonality } \\
\text { 3. Getting out of } \\
\text { backwardness } \\
\text { 4. Willing to build } \\
\text { 5. Willing to go forward }\end{array}$ & $\begin{array}{l}\text { 1. Mindset of being farmer } \\
\text { is still more dominant } \\
\text { than being service } \\
\text { provider } \\
\text { 2. The community's } \\
\text { poor consciousness of } \\
\text { tourism importance }\end{array}$ & $\begin{array}{l}\text { Service provider of } \\
\text { tourist need such as } \\
\text { homestay, shuttle, } \\
\text { stall, and etc }\end{array}$ \\
\hline
\end{tabular}

Source: adapted from the data of interview and observation result.

the village institution in a limited manner. This discussion is intended to seek the input to whether there is an addition or reduction to the concept made by the small team. From the result of discussion with limited village institution, vision and mission are formulated. The vision formulated is the realization of productive, beautiful, orderly, safe, and religious tourist village. After the vision and mission have been formulated, the next step is to discuss along with all village institutions existing in Bleberan Village and to develop village's medium-term development plan (RPJMDes). After everything has been ready, it is then socialized to society. Socialization is intended to build the community's awareness of the importance of tourist village. It is because only through such the awareness can the community be invited to participate actively in building tourist village in their area.

The third step is to develop a strategy. Bambang said that the factor to be considered in developing strategy is, among others, actor. The actor is the one who can help make the dream come through. He said:

"What we do in developing strategy is, firstly, identifying those that can help make the dream come true. It can be done by inviting the brave citizens, who are brave to stand in the front and sacrifice bravely. It is those people to whom we register in administrator to be the role model for others .... In addition, we can also invite the influential outsiders such as company's CSR to construct the necessary infrastructure" (Interview with Bambang as the members of 
Bleberan Tourist Village Initiator Team).

Furthermore, Bambang explained that the strategy to attract the tourists to stay longer in Bleberan is $3 \mathrm{D}$ : dilihat (observed), dilakukan (done), and dikenang (memorized). The tourists who came to Bleberan should be shown some available objects, so that they will not be bored by staying in one tourist object only. For that reason, the important role of tourist guide is in explaining and offering tourist objects to the visitors. Subsequently, some attempts can be taken to make the visitors stay longer. This strategy requires the existence of tourism organizer to develop attractive tour packages. Karawitan performance, for example, is not only performed by the main character but also offered to the tourist who interested in performing it along with the main characters. Tiwul cake is not only presented as typical local food, but also offered to the tourists to cook it. Finally, the tourist object of beauty, comfort, and safety to live in, and tourist guide's friendliness should be the memory for the coming tourists.

The fourth steps in the attempt of building Bleberan Tourist object are to make action and promotion. The action was done by launching the objective of promoting tourist village. The launching was conducted on July 3, 2010 by inviting stakeholders and journalists. In addition, it was done by leaflet, brochure, and film to be distributed through the tour agents. The important point in the action and promotion is that it involves the community as the marketing agent. The community which bring the tourists with them to visit the tourist village location will be given $20 \%$ reward with the condition that they should report it to the organizer one day ahead before the guest comes. This method, in addition to be effective as a promotion tools, can in fact, facilitate the tour organizer in governing the traffic toward the tour location, because of the very narrow road so that it is impossible for big vehicles like buses to intersect.

\section{The Attempt of Empowering the Community Economically}

Economic community empowerment is the attempt of helping the community to improve their welfare independently. This attempt is not easy but complicated, taking time, needing reliable and professional personnel. For that reasons, according to Triharjono, economic community empowerment in Bleberan Village cannot be done haphazardly, and should be done with mature planning. Economic community empowerment process works adjacently with the development of Bleberan Tourist Village, despite some measures taken differently from the tourist village development measures in a certain way.

The measure taken in the attempt of empowering Bleberan community economically is first to grow consciousness. Growing consciousness, according to Triharjono is the foundation for empowerment process. Without the consciousness grown from the community, empowerment is useless. It is because the community consciousness of changing their fate is the key to a successful empowerment. This consciousness growing is conducted both individually and collectively. Individually, consciousness growing is done by visiting the members of society at home, in farmland, poskamling (mobile safeguarding post) or in other places by discussing the potency they have. For example, those having a sufficiently wide house are invited to discuss the possibility of building homestay for the tourists, those with communicating skill are invited to discuss the possibility of becoming a tourist guide, and etc. Collectively, the consciousness growing is conducted along with the socialization of tourist village development. This consciousness growing is conducted by discussing any opportunity that can be utilized by anyone either individually or in the group to open job opportunity.

The second measure is to provide the facility to open job opportunity. The tour supporting facilities such as parking lot, souvenir market or food stall areas, toilet, and etc are very desirable to make the tourists feel secure and comfortable. Those facilities can also be functioned as the place for an opening job opportunity for the local communities. For that reason, according to Harno, such the facility development is put as closely as possible to tour destination. Nevertheless, the positioning of such the facilities should be arranged appropriately in order to be useful actually. In Bleberan tourist object, those facilities are arranged in ordered way from the parking lot, market area, to tour destination of Sri Gethuk waterfall. Sri Gethuk waterfall is the main tourist destination in Bleberan Tourist Village. Tourists are not allowed to drive any vehicle passing through the market area, moreover to the waterfall tour location. This arrangement and regulation are intended "to compel" the tourists to visit the market 
Table 2

Classification of Labor Absorption

\begin{tabular}{llll}
\hline Before & After & Status of Occupation & Number \\
\hline Unemployed & Tour employees & Main/ Permanent & 87 persons \\
Unemployed & Stall owner & Main/ Permanent & 41 persons \\
Employed & Tour employee & Main/ Permanent & 15 persons \\
Employed & Stall owner & Side job & 11 persons \\
Employed & Culinary & Side job & 24 persons \\
Employed & Industry & Side job & 47 persons \\
\hline
\end{tabular}

Source: Data of Field Survey on December 2015

and to buy the products sold as the gift.

The third measure is to practice the skill. The skill training is intended to empower the community in order to be willing and able to involve in managing the tourist village. It is important recalling that without support from tourist villagers will have less meaning and objective. Community behavior in interacting with tourists, the activity along with tourists, and information exchange with tourist can determine the tourists' length of staying in a tourist location. In other words, the local community's friendliness to tourists becomes determinant of a tourist object's success in attracting the tourists to stay longer in tourist location. For that reason, skill training emphasized on Bleberan Tourist Village includes tour guide training, training concerning how to welcome the guest for homestay owner and outbound training. This training can be done in cooperation with Tourism Office. In addition, education can be the focus of attention for the organizer of Bleberan Tourist Village. The attempt of improving English fluency for tour guide stars to be promoted. It is because the tourists coming to Bleberan village are dominated not only by domestic but also by foreign tourists.

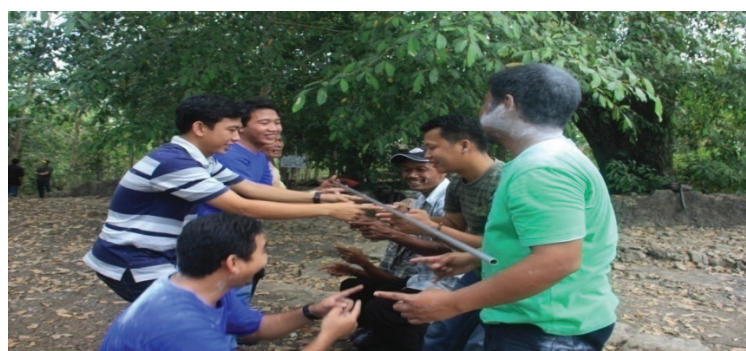

Figure 4. Outbond Training for Tour Guide

\section{The Effect of Tourist Village Develop- ment on the Community's Economy}

Theoretically, tourist development in an area can impact on economic growth in that area (Sudiarta, 2005: 4; Ashar, et al., 2009: 10-22). Similarly, the development of Bleberan Tourist Village as the tourist object and attraction in Playen Sub District of Gunung Kidul Regency exerts an economic effect that can be enjoyed directly by the local communities. The economic effect of this tour village development included the opened job opportunity and the increased income and investment.

Bleberan Tourist Village has absorbed 102 workers as tour employees, 52 persons opening their own business in souvenir market and food stall, 6 groups opening culinary business to cater to the group guests, and 9 groups opening industrial business to serve the group guests' activity. Out of that number, 143 persons admit that they get the main job, while the rest admit getting a side job. The detailed information can be seen in the Table 2.

The reason of why respondents are preoccupied with the main job in Bleberan Tourist Village is that their income is still small, despite uncertainty. As suggested by one of tourist employees, Nuryanto stated:

"We find job difficultly now, moreover the
routine job. All praises to Allah (Alhamdulillah)
we can work here ... yeah when we are asked
about what our monthly salary, the answer is
"not much", we are paid weekly. I get the salary
of IDR 280,000 every Monday here per month,
and it is given every Monday. Our salary is
about IDR 1,200,000 per month when we work
everyday. It is better than unemployed."

In the same vein, Inah, the food seller occupying the market area provided by the tourist village organizer, said:

\footnotetext{
"There are many buyers everyday. The visitors usually are so crowded on Saturday and Sunday. If it is crowded, the profit will be large, sometimes we got net profit of IDR 50,000-IDR $75,000,-$ while on workday we got only about IDR 30,000 per day. It is not too bad (it can be the main job)."
} 
Table 3

The improvement of Income in Main Job

\begin{tabular}{|c|c|c|c|}
\hline Before & After & Number & Percentage \\
\hline No income & < IDR 750,000,- & 19 persons & 13.3 \\
\hline No income & $\begin{array}{l}\text { > IDR. } 750,000,-- \text { IDR. } \\
1,000,000,-\end{array}$ & 30 persons & 20.9 \\
\hline No income & $\begin{array}{l}>\text { IDR } 1,000,000,-- \\
\text { IDR. } 1,250,000,-\end{array}$ & 44 persons & 30.8 \\
\hline No income & $\begin{array}{l}>\text { IDR } 1,250,000,-- \text { IDR } \\
1,500,000,-\end{array}$ & 35 persons & 24.5 \\
\hline $\begin{array}{l}\text { Having income < IDR } \\
750,000,-\end{array}$ & $\begin{array}{l}<\text { IDR } 1,500,000,-- \text { IDR } \\
2,000,000,-\end{array}$ & 8 persons & 5.6 \\
\hline $\begin{array}{l}\text { Having income > IDR } \\
750,000,-\end{array}$ & $\begin{array}{l}\text { > IDR } 1.500 .000,-- \text { IDR } \\
2,000,000,-\end{array}$ & 4 persons & 2.8 \\
\hline $\begin{array}{l}\text { Having income }>\text { IDR } \\
1,000,000,-\end{array}$ & $\begin{array}{l}>\text { IDR } 2,000,000,-- \text { IDR } \\
3,000.000,-\end{array}$ & 3 persons & 2.1 \\
\hline Total & & 143 persons & 100 \\
\hline
\end{tabular}

Source: Field Survey Data on December 2015

Table 4

The Improvement of Income in Side Job

\begin{tabular}{|c|c|c|c|}
\hline Before & After & Number & Percentage \\
\hline$<$ IDR 1,000,000,- & $\begin{array}{l}>\text { IDR } 1,250,000,-- \text { IDR } \\
1,500,000,-\end{array}$ & 22 persons & 26.8 \\
\hline $\begin{array}{l}>\text { IDR } 1,000,000,-- \\
\text { IDR } 1,500,000,-\end{array}$ & $\begin{array}{l}>\text { IDR } 1,500,000,-- \text { IDR } \\
2,000,000,-\end{array}$ & 39 persons & 47.6 \\
\hline $\begin{array}{l}>\text { IDR } 1,500,000,-- \\
\text { IDR 2,000,000,-- }\end{array}$ & $\begin{array}{l}>\text { IDR } 2,000,000,-- \text { IDR } \\
4,000,000,-\end{array}$ & 21 persons & 25.6 \\
\hline Total & & 82 persons & 100 \\
\hline
\end{tabular}

Meanwhile, the respondents work in Bleberan Tourist Village as side job to increase their income. As Wardi explained:

\begin{abstract}
"I trade here everyday, yeah, when I have leisure time, usually on weekend (Saturday and Sunday), but sometimes I do not so. Uncertainly. I often trade when the visitors are crowded or when there are group guests.... It is merely a side job rather than main job. Yeah, it is as if like looking for secondary livelihood while watching some event, and looking for entertainment."
\end{abstract}

Considering the information explored through survey, most respondents stated that there is an improvement of income obtained after the establishment of tourist village. The improvement of income occurs in both main and side jobs.

Meanwhile, the improvement of income from the side job the communities are preoccupied with can be seen in the Table 4 .
Bleberan Tourist Village also impacts on the community investment. The growth of Bleberan Tourist Village encourages the community to invest directly in the tourism business. The capital of tourism business such as shuttle and homestay comes from the local community. Currently there are 7 owners of shuttle lease their vehicles for transportation in tourist area, and 25 homestays leased. In addition, public toilet is also constructed in some places, such as beside Goa Rancang Kencono, parking lot, and near the waterfall with well-maintained cleanliness.

\section{Conclusions}

The attempt taken by the government of Bleberan village, Playen Sub District, Gunung Kidul Regency in building public welfare, among others, is to develop tourist village. This tourist village development was 
conducted in two steps: firstly, exploring potencies, building a dream, developing strategy, and taking action. Secondly, it was also done by building the entrepreneurial consciousness among the communities, providing the business facility, and training the business skill. Those attempts, in fact, have been successful and impacted positively on the community economy, as indicated with, among others, the opened job opportunity, the improved income of the community, and the growth of investment from local community.

\section{References}

Ashar, K., Fitanto, B., Supartono. (2009). Studi Pengembangan Ekonomi Kerakyatan Di Kawasan Wisata Jawa Timur Melalui Penguatan Kelembagaan Sosial Ekonomi Masyarakat Lokal. Journal of Indonesian Applied Economic. Vol 3. No 1: 10-22.

Damanik, J. (2009). Isu-isu Krusial Dalam Pengelolaan Desa Wisata Dewasa Ini. Jurnal Kepariwisataan Indonesia. Vol 5. No 3: 127-137.

Hadiwijoyo, S.S. (2012). Perencanaan Pariwisata Pedesaan Berbasis Masyarakat. Yogyakarta: Graha IImu.

Haryani. (2014). Potensi Pengembangan Atraksi Wisata Kampung Nelayan Pasie Nan Tigo Padang Di Tengah Ancaman Bencana Abrasi. Mimbar. Vol 30. No 2:
189-198.

Muslim, A. (2014), Model Pemberdayaan Ekonomi Masyarakat Miskin Perkotaan Berbasis Tanggung Jawab Sosial Masjid, Dissertation, Surakarta: Program Doktor Penyuluhan Pembangunan/ Pemberdayaan Masyarakat UNS.

Oktini, D.R. (2004). Peran Perguruan Tinggi, Pemerintah Dan Investor Dalam Membangun Wisata Pedesaan Di Jawa Barat Sebagai Upaya Mengurangi Kemiskinan. Mimbar. Vol 23. No 2: 255270.

Permanasari, I. (2010). Pengentasan Kemiskinan Melalui Pemberdayaan Masyarakat di Desa Wisata. Jurnal Kepariwisataan Indonesia. Vol 5. No 1: 57-69.

Prayogi, P.A. (2011). Dampak Perkembangan Pariwisata Di Objek Wisata Penglipuran. Jurnal Perhotelan dan Pariwisata. Vol 1. No 1: 64-79.

Raharjana, D.T. (2012). Membangun Pariwisata Bersama Rakyat: Kajian Partisipasi Lokal Dalam Membangun Desa Wisata Di Dieng Plateau. Jurnal Kawistara. Vol 2. No 3: 225-328.

Sudiarta, M. (2005). Dampak Fisik, Ekonomi, Sosial Budaya Terhadap Pembangunan Pariwisata Di Desa Serangan Denpasar Bali. Jurnal Manajemen dan Pariwisata. Vol 4. No 2: 1-19. 